\title{
PENGARUH PRAKTIK MENGAJAR CALON GURU EKONOMI TERHADAP KEYAKINAN EFIKASI MENGAJAR DAN MANAJEMEN KELAS (KAJIAN TEORI KOGNITIF SOSIAL)
}

\author{
Nurdian Susilowati dan Lyna Latifah \\ Fakultas Ekonomi Universitas Negeri Semarang \\ Email: nurdianakt@gmail.com
}

\begin{abstract}
Abstrak: Tujuan Penelitian adalah untuk (1) mengetahui peningkatan keyakinan efikasi mengajar sebelum dan sesudah melakukan praktik mengajar dan (2) mengetahui peningkatan keyakinan manajemen kelas sebelum dan sesudah melakukan praktik mengajar. Desain penelitian yang digunakan adalah Design One Group Pretest-Postes dengan menggunakan uji paired sample t-test. Hasil penelitian menunjukan bahwa ada peningkatan keyakinan efikasi mengajar calon guru setelah melakukan praktik mengajar berupa micro teaching. Keyakinan efikasi mengajar yang tinggi dapat menentukan kepercayaan diri mahasiswa dalam mengajar. Selain itu, mahasiswa calon guru juga mempunyai keyakinan manajemen kelas yang meningkat setelah melakukan praktik mengajar. Keyakinan manajemen kelas yang baik dapat menentukan proses pembelajaran yang efektif sehingga tujuan pembelajaran dapat tercapai.
\end{abstract}

Kata kunci: praktik mengajar, keyakinan efikasi mengajar, keyakinan mengelola kelas, mahasiswa calon guru

\section{PENGARUH PRAKTIK MENGAJAR CALON GURU EKONOMI TERHADAP KEYAKINAN EFIKASI MENGAJAR DAN MANAJEMEN KELAS (KAJIAN TEORI KOGNITIF SOSIAL) (Bahasa Inggris)}

\begin{abstract}
The purposes of this study are (1) to investigate the increase of teaching efficacy beliefs before and after field experience and (2) to reveal the increase of classroom management beliefs before and after field experience. This studi usesone group pre test-post test design using paired sample t-test. The results demonstrate the increasing pre-service teacher teaching efficacy beliefs after the field experience. The high teaching efficacy beliefs help increasestudents' self-confidence when teaching in the classroom. The classroom management beliefs are also improving after field experience. The classroom management beliefs can shape teacher effectiveness in the learning process thusthe learning objectives can be achieved.
\end{abstract}

Keywords: field experience, teaching efficacy beliefs, classroom management beliefs, pre service teacher

\section{PENDAHULUAN}

Efikasi mengajar merupakan aspek yang penting dalam dunia pendidikan sejak 25 tahun yang lalu. Efikasi mengajar diturunkan dari teori Bandura (1997), yaitu Social Cognitive Theory; pokok teori ini berkaitan dengan keyakinan diri (self efficacy). Self efficacy beliefs mengacu pada pendapat/keputusan seseorang pada kemampuan untuk mengorganisir dan melaksanakan bermacam kegiatan yang diperlukan untuk mencapai berbagai prestasi. Keyakinan tersebut merupakan faktor penting dalam pikiran/gagasan dan tindakan. Bandura (1997) menjelaskan ada dua dimensi dalam keyakinan diri yaitu personal self efficacy dan outcome expectacy. Calon guru memiliki keyakinan bahwa mampu mengorganisir dan melaksanakan perkuliahan untuk menjadi guru profesional. Sedangkan outcome expectations menunjukan bahwa calon guru memiliki harapan yang baik dalam menghasilkan performa mengajar.

Jika dikaitkan dengan performa mengajar, maka tinggi rendahnya efikasi mengajar dapat ditentukan melalui Personal Teaching Efficacy $(P T E)$. Calon guru dengan level PTE yang tinggi yakin bisa menenentukan strategi pembelajaran dan cara mengembangkannya dengan baik dan benar sehingga tujuan pembelajaran dapat tercapai. Untuk melihat hasil yang diperoleh (outcome expectation) adalah melalui General Teaching 
Efficacy (GTE) dan diperluas dengan pandangan calon guru terhadap kemampuan diri untuk menjadi seorang guru. Calon guru dengan GTE yang rendah berarti dia tidak bisa memotivasi siswa yang semuanya lebih dipengaruhi oleh faktor lingkungan.

Gibson \& Dembo (1984:570) menemukan bahwa keyakinan guru dalam mengajar berpengaruh terhadap mengajar yang efektif (GTE) dan kepercayaan diri akan kemampuannya (PTE) sehingga dapat meningkatkan prestasi akademik. Selain itu, akan terjadi feedback yang baik antara guru dan siswa. (Enochs \& Riggs (1990:694-706) menjelaskan bahwa efikasi diri dapat digunakan untuk melihat affective reactions dan perilaku dalam pembelajaran. Efikasi mengajar juga memiliki pengaruh yang positif terhadap keyakinan pengelolaan kelas dan pembelajaran (Ross, 1994; Soodak \& Podell: 1994). Pengelolaan kelas merupakan salah satu aspek yang menentukan keberhasilan proses pembelajaran dan menjadi fokus bagi guru maupun calon guru.

Manajemen kelas merupakan faktor penting yang sangat mempengaruhi prestasi belajar siswa dan lingkungan belajar mengajar yang efektif. Youseff (2003) mendefinisikan disiplin kelas dan manajemen kelas hampir memiliki arti yang sama. Namun, disiplin biasanya mengacu pada struktur dan aturan untuk perilaku siswa dan upaya untuk memastikan bahwa siswa mematuhi aturan tersebut (Martin \& Yin, 1997). Dalam penelitian ini, manajemen kelas lebih luas dibandingkan dengan disiplin kelas.

Keberhasilan manajemen kelas merupakan salah satu hal yang penting bagi pembelajaran yang efektif. Keyakinan guru terhadap kemampuannya mengajar di dalam kelas dan memfasilitasi siswa akan berpengaruh terhadap perilaku manajemen kelasnya (Henson, 2001). Walaupun manajemen kelas dan pembelajaran yang efektif saling mempengaruhi, banyak penelitian mengindikasikan bahwa calon guru tidak mengetahui bahwa mereka harus menyiapkan program pembelajaran dan keyakinan pengendalian kelas (Laut, 1999). Selain itu, guru berpikir mereka harus bisa melakukan pengelolaan kelas yang efektif akan tetapi ketika mereka tidak bisa melakukannya dapat mengakibatkan stres (Silvestri, 2001; Youseff, 2003). Oleh karena itu diperlukan kesiapan diri dalam mengajar dan pengalaman mengajar yang baik untuk menghindari kegagalan dalam pengelolaan kelas. Pengembangan keyakinan efikasi mengajar dan manajemen kelas pada calon guru menjadi topik yang menarik bagi para peneliti.

Pintrich (1990: 826-857) mengemukakan bahwa keyakinan guru akhirnya akan terbukti menjadi aspek yang paling berharga dalam membangun psikologis untuk pendidikan calon guru. Beberapa penelitian menunjukan bahwa praktik mengajar () mengajar mempengaruhi keyakinan manajemen kelas dan kayakinan efikasi guru. Praktik mengajar memberikan kesempatan bagi calon guru untuk mengumpulkan informasi tentang kepribadian calon guru serta kemampuannya dalam mengajar (Katrina, 2004: 55). Meskipun calon guru sudah mempelajari ilmu mengajar (paedagogik) dalam perkuliahan, ketika mereka dihadapkan pada realita pembelajaran yang sebenarnya banyak yang tidak bisa mengimplementasikannya. Oleh karena itu, dalam penelitian ini akan mengkaji tentang pengaruh praktik mengajar terhadap keyakinan efikasi mengajar dan keyakinan pengelolaan kelas menurut teori kognitif sosial yang dikembangkan oleh Bandura.

Berdasarkan uraian di atas, tujuan penelitian ini adalah untuk mengetahui peningkatan keyakinan (1) efikasi mengajar sebelum dan sesudah melakukan praktik mengajar dan (2) manajemen kelas sebelum dan sesudah melakukan praktik mengajar.

\section{METODE}

Rancangan penelitian ini menggunakan desain penelitian praeksperimental (Nasir, 2005: 230-232). Desain yang digunakan adalah Design One Group Pretest-Posttest. Dalam desain ini, kepada unit percobaan dikenakan perlakuan dua kali pengukuran. Pengukuran pertama dilakukan sebelum perlakukan diberikan (sebelum melakukan praktik mengajar) dan pengukuran kedua dilakukan sesudah perlakukan dilaksanakan (setelah melakukan praktik mengajar). Desain ini dapat digambarkan sebagai berikut.

Pengukuran (Pretest) Perlakuan Pengukuran (Posttest) $\mathbf{T}_{\mathbf{0}}$

$\mathrm{X} \quad \mathrm{T}_{1}$

Penelitian ini dilakukan pada kelas micro teaching. Percobaan dilakukan pada kelompokkelompok mahasiswa untuk melihat keyakinan efikasi mengajar dan pengelolaan kelas pada mahasiswa sebelum dia melakukan praktik mengajar dan setelah melakukan praktik mengajar. Pertama-tama diukur mean dari keyakinan efikasi 
mengajar dan keyakinan pengelolaan kelas dengan mengadakan pretest. Sesudah melakukan praktik mengajar diukur lagi keyakinan efikasi mengajar dan keyakinan pengelolaan kelas dengan menggunakan posttest. Kemudian dibuat perbandingan antara mean keyakinan efikasi mengajar dan keyakinan pengelolaan kelas $\left(\mathrm{T}_{0}\right.$ dan $T_{1}$ ) untuk melihat pengaruhnya. Selanjutnya akan dibandingkan pencapaian Keyakinan Efikasi Mengajar dan Keyakinan Pengelolaan Kelas dengan menggunakan uji paired sample t-test.

Populasi pada penelitian ini adalah mahasiswa Pendidikan Ekonomi yang sedang menempuh mata kuliah strategi belajar mengajar dan praktik mengajar. Selain itu, mereka telah menempuh mata kuliah perencanaan pembelajaran serta evaluasi pembelajaran. Dalam penentuan jumlah sampel yang akan digunakan dalam penelitian ini diambil dengan menggunakan rumus Slovin dalam Husein (2003:41) yakni sebagai berikut:

$$
n=\frac{N}{1+N e^{2}}
$$

Keterangan:

$\mathrm{n}=$ ukuran sampel

$\mathrm{N}=$ ukuran populasi

$\mathrm{e}=$ persen kelonggaran ketidaktelitian karena kesalahan pengambilan sampel yang masih dapat ditolerir. Persen kelonggaran yang digunakan adalah 5\%.

Dari rumus tersebut didapat 172 mahasiswa sebagai sampel. Selanjutnya pengambilan sampel menggunakan teknik proportionate random sampling. Pendistribusian sampel didasarkan pada proporsi jumlah mahasiswa penjurusan dengan rumus (Riduan \& Kuncoro, 2011:57) sebagai berikut:

$$
\mathrm{ni}=\frac{\mathrm{Ni}}{\mathrm{N}} \mathrm{n}
$$

Keterangan:

ni $=$ jumlah sampel menurut stratum

$\mathrm{n}=$ jumlah sampel seluruhnya $=172$

$\mathrm{Ni}=$ jumlah populsi menurut stratum

$\mathrm{N}=$ jumlah populasi seluruhnya $=335$

Data jumlah populasi dan sampel penelitian ditunjukkan pada Tabel 1.
Tabel 1. Populasi dan Sampel Penelitian

\begin{tabular}{lcc}
\hline Jurusan Pend. Ekonomi & Populasi & Sampel \\
\hline Pendidikan Akuntansi & 135 & 69 \\
\hline $\begin{array}{l}\text { Pendidikan Adm. } \\
\text { Perkantoran }\end{array}$ & 100 & 51 \\
\hline Pendidikan Koperasi & 100 & 51 \\
\hline Total & 335 & 172 \\
\hline
\end{tabular}

Teknik pengumpulan data yang digunakan dalam penelitian ini adalah dengan menggunakan kuesioner. Penyebaran kuesioner untuk pengumpulan data dalam penelitian ini dilakukan secara langsung oleh peneliti. Metode analisis data yang digunakan adalah analisis inferensial menggunakan uji paired sample t-test. Uji validitas dilakukan dengan melakukan korelasi bivariate antara masing-masing skor indicator dengan total skor konstruk. Skor pada item menyebabkan skor total menjadi tinggi atau rendah, sehingga dapat dikemukakan bahwa sebuah item memiliki validitas yang tingg jika skor pada item mempunyai kesejajaran dengan skor total. Kriteria instrumen dikatakan valid atau tidak tergantung pada hasil output yang dilihat pada nilai probabilitas ( $p$-value) dibandingkan dengan taraf signifikan 0,05 . Apabila $p$-value $<0,05$ maka instrument dikatakan valid, sedangkan jika $p$-value $>0,05$ maka soal dikatakan tidak valid.

Reliabilitas instrumen merupakan ketetapan alat evaluasi dalam mengukur kepercayaan. Suatu tes dapat dikatakan mempunyai taraf kepercayaan yang tinggi jika tes tersebut dapat memberikan hasil yang tetap. Dalam penelitian ini, uji reliabilitas atau tidak tergantung pada hasil output yang dilihat pada nilai taraf signifikan 0,05 . Uji normalitas yang digunakan adalah menggunakan one-sample kolmogorof smirnov test.

\section{HASIL DAN PEMBAHASAN Keyakinan Efikasi Mengajar}

Hipotesisis pertama dalam penelitian ini adalah peningkatan keyakinan efikasi mengajar calon guru di kelas setelah melakukan praktik mengajar. Untuk menguji hipotesis ini maka digunakan uji paired sample t-test. Data yang digunakan dalam uji ini adalah data keyakinan efikasi mengajar sebelum praktik mengajar dibandingkan dengan keyakinan efikasi mengajar setelah praktik mengajar. Kaidah pengambilan keputusan $(\alpha=0,05)$ adalah jika nilai sig $(2$-tailed $)<$ level of 
significant $(\alpha)$ maka ada perbedaan keyakinan efikasi mengajar calon guru sebelum dan sesudah praktik mengajar. Keyakinan efikasi mengajar sebelum dan sesudah praktik mengajar ditunjukkan pada tabel 2 .

Hasil penelitian menunjukkan bahwa nilai sig $<0,05$ sehingga dapat disimpulkan bahwa Ho ditolak sehingga Ha1 yang berbunyi "terdapat perbedaan keyakinan mengajar calon guru sebelum dan sesudah kegiatan praktik mengajar" diterima. Keyakinan efikasi mengajar dengan indikator (a) kemampuan mengajar sesuai bidang; (b) perilaku personal; dan (c) outcome expectation. Persepsi mahasiswa calon guru pada kemampuan mengajar sesuai bidang studi sebelum melakukan praktik mengajar adalah 0,74 dalam kategori tinggi, dan setelah melakukan praktik mengajar sebesar 0,76 dalam kategori tinggi. Terjadi selisih 0,02 dengan skor sebelum melakukan praktik mengajar. Artinya, kemampuan mengajarnya adalah baik. Mahasiswa calon guru dapat menyampaikan materi pembelajaran dengan baik sesuai dengan pendekatan, strategi, dan metode pembelajaran yang sesuai dengan kondisi siswa. Perilaku personal mahasiswa calon guru sebelum melakukan praktik mengajar memiliki skor 0,75 dalam kategori tinggi. Sedangkan setelah melakukan praktik mengajar sebesar 0,78 dalam kategori tinggi. Terdapat selisih 0,03 dengan skor sebelum melakukan praktik mengajar. Artinya mahasiswa calon guru yakin bahwa mereka memiliki perilaku personal yang baik dalam mengajar sehingga diharapkan dapat meningkatkan hasil belajar siswa.

\section{Keyakinan Manajemen Kelas}

Hipotesis kedua dalam penelitian ini adalah peningkatan keyakinan manajemen kelas calon guru di kelas setelah melakukan praktik mengajar. Untuk menguji hipotesisi ini maka digunakan uji paired sample t-test dengan aplikasi SPSS 19. Data yang digunakan dalam uji ini adalah data keyakinanan manajemen kelas sebelum praktik mengajar dibandingkan dengan keyakinan manajemen kelas setelah praktik mengajar. Kaidah pengambilan keputusan $(\alpha=0,05)$ adalah jika nilai sig (2-tailed) $<$ level of significant $(\alpha)$ maka ada perbedaan keyakinanmanajemen kelas calon guru sebelum dan sesudah praktik mengajar. Hasil pengolahan data terlihat tersebut ditunjukkan pada Tabel 3 .

Hasil menunjukkan bahwa nilai sig $<0,05$ sehingga dapat disimpulkan bahwa Ho ditolak, sehingga Hal yang berbunyi "terdapat perbedaan keyakinan manajemen kelas sebelum dan sesudah praktik mengajar" diterima.

Selanjutnya adalah outcome expectation mahasiswa calon guru sebelum melakukan praktik mengajar adalah cukup tinggi dengan skor 0,58. Sedangkan setelah melakukan praktik mengajar mencapai tingkatan tinggi dengan skor 0,69. Artinya mereka memiliki outome expectation yang baik dalam mengajar yaitu dapat membantu siswa dalam belajar ekonomi/akuntansi, mem-

Tabel 2. Paired Sample Test

\begin{tabular}{lcccccc}
\hline & Mean & $\begin{array}{c}\text { Std. } \\
\text { Deviation }\end{array}$ & $\begin{array}{c}\text { Std. Error } \\
\text { Mean }\end{array}$ & t & df & $\begin{array}{c}\text { Sig. (2- } \\
\text { tailed) }\end{array}$ \\
\hline $\begin{array}{l}\text { Keyakinan Efikasi } \\
\text { Mengajar Sebelum }\end{array}$ & -3.43030 & 12.62654 & .98297 & -3.490 & 164 & .001 \\
$\begin{array}{l}\text { Praktik mengajar - } \\
\text { Keyakinan Efikasi }\end{array}$ & & & & & & \\
$\begin{array}{l}\text { Mengajar Setelah } \\
\text { Praktik mengajar }\end{array}$ & & & & & & \\
\hline
\end{tabular}

Tabel 3. Paired Sample Test

\begin{tabular}{lcccccc}
\hline & Mean & $\begin{array}{c}\text { Std. } \\
\text { Deviation }\end{array}$ & $\begin{array}{c}\text { Std. Error } \\
\text { Mean }\end{array}$ & t & df & $\begin{array}{c}\text { Sig. (2- } \\
\text { tailed) }\end{array}$ \\
\hline $\begin{array}{l}\text { keyakinan manajemen } \\
\text { kelas sebelum praktik } \\
\text { mengajar - keyakinan }\end{array}$ & -2.39394 & 10.31734 & .80320 & -2.980 & 164 & .003 \\
$\begin{array}{l}\text { manajemen kelas } \\
\text { setelah praktik } \\
\text { mengajar }\end{array}$ & & & & & & \\
\hline
\end{tabular}


berikan dorongan kepada siswa dalam belajar, memberikan kesempatan siswa untuk bertanya, dan yang lainnya.

Keyakinan menejemen kelas dengan indikator: (a) Instructional management; (b) People management; dan (c) Behavior management. Keyakinan manajemen kelas mahasiswa calon guru dapat dilihat dari indikator pertama yaitu instructional management yang dapat membantunya dalam mencapai tujuan pembelajaran. Salah satunya adalah dapat mengelola perilaku belajar siswa dan memberikan kebebasan kepada siswa. Skor instructional management mahsiswa calon guru sebelum melakukan praktik mengajar adalah 0,72 dalam kategori tinggi. Sedangkan setelah melakukan praktik mengajar sebesar 0,75 . Terdapat selisih 0,03 antara sebelum dan sesudahnya. Artinya instructional management mahsiswa calon guru adalah baik. Indikator kedua adalah people management artinya kesepakatan antara guru dengan siswa dan siswa dengan siswa terkait dengan pembelajaran yang akan dilakukan.

People management calon guru sebelum melaksanakan praktik mengajar adalah tinggi dengan skor 0,78 . Sedangkan setelah melakukan praktik mengajar adalah tinggi dengan skor 0,80 dalam kategori tinggi. Selisih diantara keduannya adalah 0,02 . Artinya mahasiswa calon guru memiliki people management yang baik dalam pembelajaran. Ketiga adalah behavioral management, yaitu kemampuan guru mengarahkan perilaku siswa di dalam kelas sehingga dapat berdampak pada hasil belajarnya. Behavioral management mahsiswa calon guru sebelum melakukan praktik mengajar adalah tinggi dengan skor 0,79 sedangkan setelah praktik mengajar 0,81 . Hal ini menunjukan bahwa behavioral management mahasiswa calon guru adalah baik.

\section{Pembahasan}

Keyakinan tentang efikasi mengajar sangat menentukan performansi mahasiswa dalam mengajar. Hal ini sesuai dengan Bandura (1997) bahwa konsepsi tentang efikasi diri menentukan pilihan perilaku, misalnya menentukan apa yang harus dilakukan oleh seorang individu. Jika dikaitkan dengan pembelajaran, praktik mengajar merupakan bentuk perilaku yang dilakukan oleh mahasiswa calon guru sebelum dia praktik menjadi guru dan menjadi guru. Faktor yang sangat menentukan mempengaruhi keyakinan efikasi mengajar adalah praktik mengajar. Pengalaman mengajar dalam bentuk praktik mengajar merupakan sebuah kegiatan mengimplementasikan pengetahuan berupa teori ke dalam pembelajaran sebelum dia menjadi guru (Katrina 2004).

Pengalaman mengajar ini memberikan kesempatan kepada calon guru untuk mengimplementasikan konten pengetahuan dan pengetahuan pedagogiknya dalam sebuah pembelajaran di dalam kelas. Mahasiswa calon guru dapat meningkatkan kemampuan personal mengajar. Hal tersebut sesuai dengan penelitian Gurvitch and Metzler (2009) ada pengaruh pengalaman mengajar mahasiswa di setiap levelnya terhadap efikasi mengajar. Woolfolk (2001) mendemonstrasikan bahwa mahasiswa calon guru memiliki efikasi mengajar yang tinggi melalui program pembelajaran dan pengalaman mengajar sebelumnya.

Selain itu, keyakinan efikasi mengajar turut menentukan besarnya usaha yang harus dilakukan dan berapa lama seseorang dapat bertahan dalam menghadapi kegagalan dan kesulitan (outcome expectations). Outcome expectations mengacu pada percaya tentang konsekuensi atau hasil perilaku yang dilakukan, misalnya jika saya mencoba menerpakan model pembelajaran berbasis masalah apa yang akan terjadi pada siswa. Bandura menyatakan bahwa keduanya (self efficacy dan outcome expectations) membantu untuk menentukan jumlah seberapa penting aspek perilaku seseorang seperti aktivitas yang orang pilih untuk mengejar dan menghindari sesuatu. Keyakinan efikasi mengajar mahasiswa calon guru bisa jadi dipengaruhi oleh ekspektasinya menjadi guru yang baik dan profesional sehingga performa mengajarnya bagus.

Jika seseorang memiliki keyakinan yang kuat tentang efikasi diri, seseorang dapat bertahan menghadapi tugas yang sulit. Selain itu, keyakinan efikasi diri mempengaruhi pikiran dan perasaan seseorang. Ketika mahasiswa melakukan praktik mengajar akan muncul berbagai macam tindakan terkait dengan performansinya dalam proses pembelajaran di kelas. Jika mahasiswa memiliki keyakinan efikasi mengajar yang tinggi maka akan muncul semangat, kepercayaan diri, dan optimis. Akan tetapi sebaliknya, jika dia memiliki keyakinan efikasi mengajar yang rendah maka dia tidak percaya diri, tidak semangat, dan pesimis. Keyakinan memiliki efikasi mengajar dapat mendorong seseorang untuk melakukan kegiatan, sedangkan keyakinan bahwa tidak memiliki efikasi dapat membuat orang menghindari kegiatan yang 
sesungguhnya dapat memperkaya pengalamannya. Keyakinan yang berlebihan tentang efikasi sangat bersifat disfungsional. Namun, keyakinan efikasi yang mungkin paling fungsional adalah yang sedikit melewati apa yang dapat dilakukan seseorang pada saat tertentu.

Efikasi mengajar yang tinggi dapat terlihat dari kemampuan guru dalam mengatur dan melaksanakan program perencanaan pembelajaran. Bandura (1997) mengemukakan bahwa penguasaan pengalaman merupakan sumber yang paling kuat dalam efikasi mengajar. Hal tersebut bisa diartikan bahwa, keyakinan efikasi mengajar dapat dijadikan sumber keyakinan diri untuk performansi selanjutnya. Level gairah fisiologis dan emosional yang guru alami juga dapat meningkatkan performa mengajar dan keyakinan diri tersebut.

Jika ditinjau dari teori belajar kognitif, keyakinan efikasi mengajar dapat mempengaruhi perkembangan keterampilan-keterampilan yang diperlukan untuk melakukan tugas-tugas yang kompleks, sedangkan keyakinan akan inefficacy dapat menghambat perkembangan tersebut. Keyakinan akan efficacy dapat dihadapkan pada disinsentif dan kendala kinerja. Teori belajar cognitive-field menaruh perhatian kepada kepribadian dan psikologi sosial. Tingkah laku merupakan hasil interaksi antar kekuatan-kekuatan, baik yang dari dalam individu seperti tujuan, kebutuhan, tekanan kejiwaan, maupun dari luar individu seperti tantangan dan permasalahan. Medan kekuatan psikologis dimana individu beraksi disebut "life space" yang mencakup perwujudan lingkungan, seperti orang-orang yang ia jumpai, objek materiil yang ia hadapi dan fungsi-fungsi kejiwaan yang ia miliki. Belajar merupakan akibat dari perubahan dalam struktur kognitif. Perubahan struktur kognitif adalah hasil dari dua macam kekuatan, satu dari struktur medan kognitif itu sendiri, yang lainnya dari kebutuhan dan motivasi internal individu.

Keberhasilan manajemen kelas merupakan salah satu hal yang penting bagi pembelajaran yang efektif dan keyakinan guru terhadap kemampuannya dalam memfasilitasi siswa yang akan berpengaruh terhadap perilaku pengelolaan kelasnya (Henson, 2001). Walaupun pengelolaan kelas dan pembelajaran yang efektif saling mempengaruhi, banyak penelitian mengindikasikan bahwa calon guru dan guru tidak mengetahui bahwa mereka harus menyiapkan program pem- belajaran dan lingkungan pengendalian kelas yang sebenarnya (Laut, 1999). Selain itu, guru berpikir bahawa mereka harus bisa menghendel pengelolaan kelas dan kadang hal tersebut mengakibatkan stres (Silvestri, 2001; Youseff, 2003). Oleh karena itu, diperlukan kesiapan diri dalam mengajar dan pengalaman mengajar yang baik untuk menghindari kegagalan dalam pengelolaan kelas.

Salah satu faktor yang menentukan keyakinan manajemen kelas adalah pengalaman mengajar yang dimiliki oleh sesorang. Jika dia memiliki pengalaman mengajar yang baik makan dapat mengelola kelas dengan baik. Karena dia dapat melakukan refleksi terhadap pembelajaran yang telah dilakukan dan memperbaikinya di pembelajaran selanjutnya. Hal tersebut dapat diartikan bahwa orang tersebut memiliki keyakinan manajemen kelas yang baik. Tiga jenis pendekatan manajemen yang berkaitan dengan keyakinan manajemen kelas adalah (1) manajemen instruksional, (2) menajemen orang, dan (3) perilaku manajemen. Ketiga dimensi tersebut sangat menentukan keyakinan manajemen kelas mahasiswa calon guru sehingga dapat menghasilkan performa mengajar yang efektif dan efisien.

Jika dikaitkan dengan manajemen instructional, maka pengelolaan kelas mengacu pada berbagai keterampilan dan teknik yang digunakan guru untuk membuat siswa terorganisir, teratur, fokus, penuh perhatian, melaksanakan tugas dengan baik, dan produktif selama kelas. Ketika mahasiswa calon guru memiliki keyakinan manajemen kelas maka dia dapat melakukan pembelajaran secara efektif, meminimalkan perilaku yang menghalangi pembelajaran bagi siswa individu dan kelompok-kelompok, sekaligus memaksimalkan perilaku yang memfasilitasi atau meningkatkan pembelajaran. Secara umum, guru yang efektif cenderung menampilkan keterampilan manajemen kelas yang kuat, sedangkan ciri khas guru berpengalaman atau kurang efektif adalah kelas kacau penuh dengan siswa yang tidak bekerja atau memperhatikan.

Sementara interpretasi terbatas atau yang lebih tradisional dari manajemen kelas yang efektif dapat fokus terutama pada "kepatuhan" rules dan strategi yang guru dapat menggunakan untuk memastikan siswa duduk di kursi mereka, berikut arah, mendengarkan dengan penuh perhatian. Mengingat pengelolaan kelas meluas ke segala sesuatu yang guru dapat lakukan untuk memfasilitasi atau meningkatkan belajar siswa, 
yang akan mencakup faktor-faktor seperti perilaku (sikap positif, ekspresi wajah bahagia, laporan menggembirakan, pengobatan hormat dan adil siswa, dan lain-lain), lingkungan (misalnya, menyambut, kelas remang diisi dengan intelektual merangsang bahan belajar yang diselenggarakan untuk mendukung kegiatan belajar tertentu), harapan (kualitas pekerjaan yang guru berharap siswa untuk menghasilkan, cara-cara yang guru berharap siswa untuk bersikap terhadap siswa lain, perjanjian bahwa guru membuat dengan siswa), bahan (jenis teks, peralatan, dan sumber daya lainnya pembelajaran yang menggunakan guru), atau kegiatan (jenis pengalaman bahwa guru desain untuk terlibat minat siswa, gairah belajar, dan rasa ingin tahu intelektual).

Hal itu dinamakan manajemen siswa. Artinya, keyakinan calon guru pada kemampuannya untuk mengelola siswa sebaik-baiknya sehingga tujuan pembelajaran dapat tercapai. Contoh lainnya adalah guru dapat mengelola siswa-siswa yang nakal dan tidak terorganisir, kesepakatan pembelajaran yang diingkari oleh siswa, dan lainnya.

Aspek perilaku manajemen yang ditampilkan oleh seorang guru adalah perilaku guru dalam mengelola kelas. Keyekinan manajemen kelas calon guru bisa meningkat bisa karena pengalaman suskes yang pernah dimiliki, penurunan level keyakinan, tugas tambahan, dan adanya banyak tugas yang diberikan sehingga siswa merasa berat untuk mengerjakannya (Ginns et al, 1995). Hasil penelitian menunjukan bahwa pengalaman pendidikan selama praktik mengajar mempengaruhi sikap mereka terhadap manajemen kelas. Ini juga konsisten dengan penelitian lain bahwa bagaimana pengalaman praktik mengajar mempengaruhi keyakinan manajemen kelas. Instruksi kelas yang efektif dalam program pendidikan guru dapat mengubah pandangan siswa tentang manajemen kelas (Hollingsworth, 1989).

Ide kreatif mahasiswa calon guru untuk melakukan pengelolaan kelas terjadi selama keyakinan manajemen kelas itu muncul pada diri seseorang dan dapat berubah setiap kali mereka tampil (Tatto, 1996). Perubahan tersebut terjadi ketika guru tersebut dipekerjakan untuk posisi pertama mereka mengajar (Laut, 1999). Pada titik ini, sikap mereka biasanya menjadi lebih intervensionis. Sokal, Smith, \& Mowat (2003) mengemukakan bahwa jelas persis di mana pada kontinum bahwa transisi antara interaksionis dan intervensionis sikap menjadi bermasalah. Selain itu, guru menjadi lebih intervensionis dalam satu komponen manajemen kelas dan kurang kreatif dalam melakukan proses pembelajaran. Oleh karena itu, mahasiswa calon guru harus yakin terhadap kemampuan yang dia miliki sehingga tidak terjadi intervensional sikap yang dapat menyebabkan sebuah masalah pembelajaran.

\section{SIMPULAN}

Hasil penelitian menunjukan bahwa pertama, terjadi peningkatan keyakinan efikasi mengajar setelah mahasiswa calon guru melakukan praktik mengajar. Hal tersebut sangat membantu mahasiswa kelak ketika melakukan Praktik Pengalaman Lapangan (PPL) di sekolah-sekolah latihan dan mempersiapkan diri sebagai guru yang profesional. Selain itu, mahasiswa calon guru juga memiliki keyakinan efikasi mengajar yang tinggi. Hal tersebut terlihat dari kemampuan mengajarnya ketika melakukan praktik mengajar di kelas. Keyakinan efikasi mengajar sangat diperlukan untuk menunjang kemampuan mengajar yang baik. Kedua, mahasiswa calon guru mempunyai keyakinan manajemen kelas yang meningkat setelah melakukan praktik mengajar. Keyakinan manajemen kelas yang baik dapat menentukan proses pembelajaran yang efektif sehingga tujuan pembelajaran dapat tercapai. Keyakinan manajemen kelas juga dapat mengantarkan siswa untuk memperoleh hasil belajar yang baik.

\section{UCAPAN TERIMA KASIH}

Terima kasih kepada mahasiswa Jurusan Pendidikan Ekonomi Universitas Negeri Semarang dan semua pihak yang telah memberikan kesempatan untuk melakukan penelitian sehingga artikel ini dapat diselesaikan. Selain itu kami mengucapkan terima kasih kepada Bapak Yeri sebagai reviwer penelitian Unnes yang telah memberikan masukan dan penyempurnaan penelitian. Semoga artikel ini bermanfaat dan menginspirasi semua pihak. Amin

\section{DAFTAR PUSTAKA}

Bandura, A. 1997. Self-efficacy: The Exercise of Control. New York: Freeman and Company.

Enochs, L. G. \& Riggs, I. M. 1990. "Further Development of an Elementary Science Teaching Efficacy Belief Instrument: A 
Preservice Elementary Scale." School Science \& Mathematics, 90, 694-706.

Gibson, S., \& Dembo, M. 1984. "Teacher Efficacy: A Construct Validation." Journal of Educational Psychology, 76,569-582.

Ginns, I. S. \& Watters J. J. 1996. "Experiences of Novice Teachers: Changes in Self-Efficacy and Their Beliefs about Teaching." New York: Annual Meeting of The American Educational Research Associations.

Gurvitch, R., \& Metzler, M. W. 2009. "The Effects of Laboratory-based and Field-based Practicum Experience on Pre-service Teachers' Self-Efficacy." Teaching and Teacher Education, 25, 437-443

Henson, R. K. 2001. Relationships Between Preservice Teachers'Selfefficacy, Task Analysis, and Classroom Management Beliefs. Paper presented at the annual meeting of the Southwest Educational Research Association, New Orleans, LA.

Hollingsworth, S. 1989. "Prior Beliefs and Cognitive Change in Learning to Teach." American Educational Research Journal, 26, 160-189.

Hoy, W. K., \& Miskel, C. G. 2001. Educational administrator: Theory, research, and practice (6th ed.). Boston: McGraw-Hill

Katrina, M. 2004. Lessons learned: Reflecting back on student teaching. Unpublished Master Thesis, Department of Middle and Secondary Education, The Florida State University College of Education. Retrieved October 16, 2006, from http://etd.lib. fsu.edu/theses/available/etd- 05052004204003

Laut, J. 1999. Classroom Management: Beliefs of Pre-service Teacher and Classroom Teachers Concerning Classroom Management Styles. Paper presented at the Fall Teachers Education Conference, Charleston, SC.

Martin, N. K., \& Baldwin, B. 1997. "Validation of an Inventory of Classroom Management
Style: Diffierences Between Novice and Experienced Teachers." Paper presented at the annual meeting of the American Educational Research Association, Atlanta, GA.

Nasir, M. 2005. Metode Penelitian. Jakarta: Rineka Cipta

Pintrich, P. R. 1990. "Implications of Psychological Research on Student Learning and College Teaching for Teacher Education." In W. R. Houston (Ed.), Handbook of Research on Teacher Education (pp. 826-857). New York: Macmillan.

Ross, J. A. 1994. Beliefs that Make a Difference: The Origins and Impacts of Teacher Efficacy (Eric Document Reproduction Service No. ED 379 216).

Silvestri, L. 2003. The Effect of Attendance on Undergraduate Methods Course Grades. Education, 123 (3), 483-487. Retrieved December 23, 2006, from http://www. findarticles.com/p/articles/mi_qa3673/is_ 200304/ai_n9232366

Sokal, L., Smith, D. G., \& Mowatt, H. 2003. “Alternative Certification Teachers' Attitudes Towards Classroom Management." High School Journal. 86 (3), 8-16.

Soodak, L.C., \& Podell, D. M. 1994. "Teachers' Thinking About Difficult-to-Teach Students." Journal of Educational Research, 88 (1), 44-51.

Tatto, M. T. 1996. Examining Values and Beliefs about Teaching Diverse Student: Understanding the Challenges for Teacher Education. Educational Evaluation and policy analysis. 18 (2), 155-180.

Woolfolk, A. 2001. Educational Psychology (8th ed.). Boston: Allyn \& Bacon.

Youseff, G. 2003. An Investigation Into the Influences of Teachers' Classroom Management Beliefs and Practices on Classroom Procedures. Paper presented at Association for Research in Education. Retrieved October 16, 2006, from www.aare.edu.au/03pap/ you03353.pdf 